\title{
Protocol
}

\section{Effects of Psychiatric Comorbidity in Immune-Mediated Inflammatory Disease: Protocol for a Prospective Study}

Ruth Ann Marrie ${ }^{1}$, MD, PhD; Lesley Graff ${ }^{1}, \mathrm{PhD}$; John R Walker ${ }^{1}$, PhD; John D Fisk ${ }^{2}$, PhD; Scott B Patten ${ }^{3}$, MD, $\mathrm{PhD}$; Carol A Hitchon ${ }^{1}$, MSc, MD; Lisa M Lix ${ }^{1}$, PhD; James Bolton ${ }^{1}, \mathrm{MD}$; Jitender Sareen ${ }^{1}$, MD; Alan Katz ${ }^{1}$, MSc, MBChB; Lindsay I Berrigan ${ }^{4}$, PhD; James J Marriott ${ }^{1}$, MSc, MD; Alexander Singer ${ }^{1}$, MBBChBAO; Renée El-Gabalawy ${ }^{1}, \mathrm{PhD}$; Christine A Peschken ${ }^{1}$, MD; Ryan Zarychanski ${ }^{1}, \mathrm{MSc}, \mathrm{MD}$; Charles N Bernstein ${ }^{1}, \mathrm{MD}$

\footnotetext{
${ }^{1}$ University of Manitoba, Winnipeg, MB, Canada

${ }^{2}$ Dalhousie University, Winnipeg, MB, Canada

${ }^{3}$ University of Calgary, Calgary, AB, Canada

${ }^{4}$ St. Francis Xavier University, Antigonish, NS, Canada
}

\section{Corresponding Author:}

Ruth Ann Marrie, MD, PhD

University of Manitoba

GF 543-820 Sherbrook Street

Winnipeg, MB, R3A 1R9

Canada

Phone: 12047874951

Fax: 12047871486

Email: rmarrie@hsc.mb.ca

\section{Abstract}

Background: Immune-mediated inflammatory diseases (IMID), such as inflammatory bowel disease (IBD), multiple sclerosis (MS), and rheumatoid arthritis (RA), are highly prevalent in Canada and the United States and result in substantial personal and societal burden. The prevalence of psychiatric comorbidities, primarily depression and anxiety, in IMID exceeds those in the general population by two- to threefold, but remains underdiagnosed and undertreated. Furthermore, the effects of psychiatric comorbidity on IMID are not well understood.

Objective: The objectives of this study were (1) to compare health-related quality of life and work ability in persons with IMID and psychiatric comorbidity with those of persons with IMID without psychiatric comorbidity and with those of persons with depression and anxiety disorders alone, and (2) to validate existing case identification tools for depression and anxiety in persons with IMID to facilitate improved identification of depression and anxiety by clinicians. To achieve these objectives, we designed a prospective 3-year longitudinal study. In this paper, we aim to describe the study rationale and design and the characteristics of study participants.

Methods: Between November 2014 and July 2016, we recruited 982 individuals from multiple clinic and community sources; 18 were withdrawn due to protocol violations.

Results: The final study sample included 247 participants with IBD, 255 with MS, 154 with RA, and 308 with depression or anxiety. The majority were white, with the proportion ranging from 85.4\% (IBD [210/246]; MS [217/254]) to 74.5\% (114/153, RA; $P=.01)$. There was a female predominance in all groups, which was highest in the RA cohort $(84.4 \%, 130 / 154)$ and least marked in the IBD cohort $(62.7 \%, 155 / 247)$. Participants with depression or anxiety were more likely to be single $(36.0 \%, 111 / 308)$ than participants in any other group (11.8\% [30/255]-22.7\% [56/247], $P<.001)$.

Conclusions: This paper presents the rationale for this study, describes study procedures, and characterizes the cohort enrolled. Ultimately, the aim is improved care for individuals affected by IMID.

(JMIR Res Protoc 2018;7(1):e15) doi: 10.2196/resprot.8794

\section{KEYWORDS}

inflammatory bowel disease; multiple sclerosis; rheumatoid arthritis; depression; anxiety; epidemiology 


\section{Introduction}

Immune-mediated inflammatory diseases (IMID), such as inflammatory bowel disease (IBD), multiple sclerosis (MS), and rheumatoid arthritis (RA), are highly prevalent in Canada and the United States, and substantially burden affected individuals and society [1-4]. Persons with IBD, MS, and RA report poorer health-related quality of life (HRQOL) as compared with the general population [5-8]. They are also at increased risk of leaving the workforce early due to disease-related disabilities [9-11].

\section{Psychiatric Comorbidity}

Increasingly, psychiatric comorbidity, including depression and anxiety disorders, is recognized as common among individuals with IMID, with a prevalence exceeding that in the general population by two- to threefold. Psychiatric disorders are commonly associated with adverse health outcomes, including impaired HRQOL and missed work [12,13]. The effects of psychiatric comorbidity on HRQOL and work ability in those with IMID, beyond the impact of the IMID itself, are not well understood. Most studies have focused on the impact of the IMID on cessation from paid work, but this fails to capture the spectrum of functional work impairment. Presenteeism (reduced productivity while at work due to illness) and absenteeism (missed work due to illness) have received much less attention, including how they are affected by psychiatric comorbidity [14-16]. Moreover, prior studies have often been cross-sectional and included small samples.

Several potential mechanisms may underlie the association between psychiatric morbidity and adverse outcomes. Psychiatric comorbidity may lead to changes in health behaviors such as poorer diet or sleep hygiene, lower adherence to treatment, and increased smoking [17]. Complex bidirectional relationships exist between psychiatric disorders, such as depression and anxiety, and immune function [18]. Stress may play a role in psychiatric comorbidity and poor chronic disease outcomes [19-21].

Despite the adverse effects of depression and anxiety disorders on chronic disease outcomes, these psychiatric disorders are undertreated when they co-occur in IMID [22-26]. Improved detection of these disorders in IMID is a necessary step to better management. Case identification instruments (screening tools) may promote detection of depression and anxiety disorders. However, tools developed for the general population may not translate well to use for people with IMID. For example, somatic symptoms of depression (depressive affect), such as fatigue, difficulty sleeping, and poor appetite, captured in screening tools are also common somatic symptoms of IMID, which may lead to criterion contamination [27]. Similar issues arise when screening for anxiety. Therefore, screening tools must be validated in the IMID populations. To date, these validation efforts have been limited to a few tools, and evaluation of psychometric characteristics of these tools has been limited [28-30].

\section{Aims}

We designed a prospective 3-year longitudinal study of persons with IMID with 2 principal aims. The first aim was to compare HRQOL and work ability in persons with IMID and psychiatric comorbidity with those of persons with IMID without psychiatric comorbidity and with those of persons with depression and anxiety disorders alone. The second aim was to validate existing screening tools for depression and anxiety in persons with IMID to facilitate improved identification of depression and anxiety by clinicians. We expect that improved identification and management of these disorders would positively affect patient-centered outcomes such as HRQOL.

This paper describes the study design, recruitment of participants, and the characteristics of the established cohort.

\section{Methods}

\section{Design}

We enrolled participants with any of the following 5 diagnoses: (1) IBD—Crohn disease or ulcerative colitis [31,32]; (2) MS-definite diagnosis according to the Poser or revised McDonald criteria [33-36]; (3) RA-definite diagnosis based on the 2010 American College of Rheumatology/European League Against Rheumatism (ACR/EULAR) Rheumatoid Arthritis Classification Criteria [37]; (4) major depressive disorder meeting the Diagnostic and Statistical Manual of Mental Disorders (DSM-IV) criteria [38]; and (5) any anxiety disorder meeting the DSM-IV criteria [38]. As DSM-IV rather than DSM-5 was in place at the time of the study inception, post-traumatic stress disorder and obsessive compulsive disorder were included as anxiety disorders, in keeping with the DSM-IV classification scheme.

All participants were required to be aged 18 years or older (without an upper age limit), able to provide informed consent, willing to participate in the study for 3 years, and to have an adequate knowledge of the English language to complete questionnaires (this latter criterion did not exclude anyone). Diagnoses of IBD, MS, and RA were confirmed by medical records review and by querying treating physicians directly if needed. Diagnoses of depression or anxiety were confirmed by structured clinical interview as delineated below. The presence of comorbid psychiatric disorders was not an exclusion criterion.

We obtained ethics approvals from the University of Manitoba Health Research Ethics Board and research committee approval from the Winnipeg Regional Health Authority, Winnipeg Health Sciences Centre, St. Boniface Hospital, Seven Oaks Hospital, and Victoria General Hospital. All participants provided written informed consent. In addition to consenting to core study activities, participants were also asked to agree to blood sample collection at each visit and to linkage of the collected data to health administrative data records.

\section{Recruitment}

We used general and targeted strategies to recruit participants from the community and tertiary care settings. General strategies included the placement of posters in local hospitals, private medical and psychology clinics, and academic institutions within 
the Winnipeg region; use of social media outlets (tweets and Facebook posts) through the largest tertiary center (Winnipeg Health Sciences Centre); and self-help groups for mental health concerns. The targeted strategies used for each group are described below.

For IBD, research assistants directly approached individuals attending gastroenterology clinic visits using a standardized script and contacted participants in a population-based IBD research registry via email. The registry was established in 1995 by one of the investigators (CB) and includes nearly half the provincial IBD population [39].

For MS, research assistants contacted participants in the Winnipeg MS Clinic registry by phone and mail. This clinic was established in 1998 and is the sole source of care for Manitobans with MS being treated with disease-specific therapies, although the clinic population is not limited to those receiving such therapies. A research registry was established in 2011, and most of the individuals with MS attending the clinic have agreed to participate.

For RA, research assistants directly approached individuals attending scheduled clinic visits at the University of Manitoba Arthritis Centre, the tertiary care clinic for rheumatologic disease in Manitoba, using a standardized script. The University of Manitoba Arthritis Centre also contacted individuals with RA in their clinic database by mail, as did one other local community rheumatology clinic.

For depression and anxiety disorders, information about the study was included in appointment letters sent to individuals referred for psychology or psychiatry consultation at tertiary care centers within the Winnipeg region. Information letters were also mailed by primary care clinics operated in partnership by the Winnipeg Regional Health Authority and the University of Manitoba and at a local primary care practice to patients with diagnoses of depression or an anxiety disorder identified using their electronic medical records. Research coordinators also presented information about the study to individuals attending psychoeducational classes for cognitive behavioral therapy held by the Psychiatry Program at the Health Sciences Centre.

\section{Data Collection and Measures}

We collected information regarding sociodemographic characteristics, height, weight, blood pressure, physical function, cognitive function, psychiatric morbidity, and self-reported smoking status, stress, pain, fatigue, HRQOL, and work disability from all participants. Disease-specific measures tailored to each disease group were also collected. Unless otherwise specified, each of these measures was collected at study enrollment and will be collected at 3 annual study-specific assessments thereafter for a total of 4 assessments. Annual assessments will be booked within \pm 1 month of the enrollment date.

\section{Sociodemographic Characteristics}

Using questionnaires, participants reported sex, date of birth, ethnicity, total number of years of formal education, highest level of education attained, annual household income, marital status, whether they had any children (yes vs no), and current or most recent occupation. Ethnicity was captured using the categories specified by Statistics Canada in regular surveys. Highest level of education completed was reported using the following categories: elementary school, junior high school, high school diploma or General Education Diploma (GED), college, technical/trade, university bachelor's degree, university master's degree, university doctorate, and other. Annual household income was reported as less than Can \$15,000, Can $\$ 15,000-29,999$, Can \$30,000-49,999, Can \$50,000-100,000, more than Can $\$ 100,000$ or "I do not wish to answer." Responses for marital status included single/never married, married, common law, divorced, widowed, and separated. Occupation was categorized using Statistics Canada's categories as management; business, finance, and administration occupations; health occupations; occupations in education, law, and social, community, and government services; occupations in art, culture, recreation, and sport; sales and service occupations; trades, transport and equipment operators, and related occupations; natural resources, agriculture, and related production occupations; and occupations in manufacturing and utilities [40].

\section{Body Mass Index}

Research assistants measured height and weight to derive body mass index $\left(\mathrm{kg} / \mathrm{m}^{2}\right)$.

\section{Blood Pressure}

Blood pressure and heart rate were measured in the seated position using an automatic blood pressure machine.

\section{Physical Function}

We assessed lower limb function and ambulation using the timed 25-foot walk test [41-43]. This tool is considered to be a quick, reliable measure of functional capacity in older populations $[44,45]$ and has been validated for use in MS. Upper limb function was assessed using the 9-hole peg test, a validated measure used in MS [41-43] and the Arthritis Hand Function Test for RA [46]. The timed 25-foot walk test and 9-hole peg test constitute 2 of the 3 components of the Multiple Sclerosis Functional Composite [41-43], which all research assistants were certified to perform.

\section{Cognitive Function}

We selected validated neuropsychological measures to assess cognitive domains of processing speed, working memory, and verbal learning, which are often found to be affected in MS [47], RA [48], and IBD [49] as well as in depression (processing speed, working memory) and generalized anxiety disorder [50]. The measures included the Symbol Digit Modalities Test (processing speed) [51]; Wechsler Memory Scale-III Letter-Number Sequencing subtest (working memory) [52]; and California Verbal Learning Test II (verbal learning and memory) [53]. We also included the Wechsler Test of Adult Reading as a measure of premorbid intellectual functioning [54]. The extent of cognitive testing was constrained by the length of study visits and the potential for participant fatigue. Research assistants who administered the cognitive measures were trained by a psychometrician, under the supervision of a registered neuropsychologist (JDF). 


\section{Smoking Status}

We assessed smoking status because smoking may confound associations between psychiatric status and study outcomes, such as HRQOL [55-57]. Individuals who reported ever smoking $\geq 100$ cigarettes were defined as ever smokers [58] and were asked to report current smoking status (not at all, some days, every day), the age at which they had started smoking, how many cigarettes they currently smoked per day, and the number of days in the past 30 days that they had smoked. Ex-smokers reported the age at which they quit smoking cigarettes and the average number of cigarettes smoked per day during the years that they smoked.

\section{Comorbidity}

To assess self-reported physical and psychiatric comorbidities, we used questions derived from a survey validated for the general population [59] and for use for people with MS [60]. Participants reported whether a doctor has ever diagnosed them with any of the following conditions: high cholesterol, high blood pressure, heart trouble, disease of arteries in the legs, lung trouble, diabetes mellitus, cancer of the breast, cancer of the colon or rectum, cancer of the lung, skin cancer, other cancers, migraine, thyroid disease, lupus, osteoarthritis, osteoporosis, fibromyalgia, kidney disease, peptic ulcer disease, liver problems, irritable bowel syndrome, epilepsy (seizure disorder), depression, anxiety disorder, bipolar disorder, or schizophrenia. For any condition indicated as present, participants reported the year of diagnosis and whether it is currently being treated.

\section{Psychiatric Morbidity}

We assessed psychiatric morbidity at enrollment using the structured clinical interview for DSM-IV-TR Axis I Disorders-Research version (SCID), a semistructured interview to identify anxiety, mood, and substance use disorder DSM-IV diagnoses [61], all of which were captured in this study. The interviews were conducted by graduate students in clinical psychology, nurses, and research coordinators who were trained to conduct the interviews by a registered clinical health psychologist (JRW) with extensive experience with SCID. Training included review of the SCID users guide, observing video examples of interviews, detailed review of the modules, role-playing interviews, observing an interview, and being observed when administering an interview. Team members met to review interviews regularly, and consultation with more experienced team members was available when diagnostic questions were encountered.

Participants also completed several case identification (screening) instruments for depression and anxiety (Table 1) [62-68]. These instruments were selected because they were brief, easy to self-administer, and available in the public domain for clinical purposes, making them feasible to use in clinical settings. In the general population, they share features of moderate to high sensitivity and specificity [62-68]. In addition, the "Perceived Need Question" was included, which queries patients' perceived need for treatment and can improve specificity of depression screening. Responses are "no," "yes, but not today," or "yes" [69].

\section{Stress}

The Perceived Stress Scale (PSS) is widely used to measure the degree to which individuals are experiencing stress, the underlying concept being that stress is the extent to which perceived demands exceed the perceived personal resources to cope [70]. The 10-item version (PSS-10) has high internal consistency reliability and test-retest reliability, good construct validity, and predictive validity [71-74]. Scores range from 0 to 40 , with higher scores indicating greater perceived stress.

\section{Pain}

The Pain Effects Scale assesses pain, and it was originally developed and validated for the Medical Outcomes Study [75]. A reduced 6-item version (Modified Pain Effects Scale) was included in the MS quality of life inventory, and is valid and reliable [76,77]. Scores range from 6 to 30, with higher scores indicating greater pain.

\section{Fatigue}

Fatigue was evaluated using the Fatigue Impact Scale for Daily Use (D-FIS), a brief validated instrument adapted from the Fatigue Impact Scale that includes 8 items that reflect daily fatigue [78]. Each item is scored ordinally from 0 (no problem) to 4 (extreme problem), and total scores range from 0 to 32 . The D-FIS has good psychometric properties [79].

\section{Health-Related Quality of Life}

We measured HRQOL using the Short Form-36, a generic measure of HRQOL validated in the general population as well as in multiple IMID populations [80-83]. The 2 summary scales capture physical HRQOL (the physical component score [PCS]-36) and mental HRQOL (the mental component score [MCS]-36). Scores on the PCS-36 and MCS-36 range from 0 to 100 , with a mean of 50 and standard deviation of 10 ; higher scores indicate better quality of life.

\section{Work Impairment}

We used the Work Productivity and Activity Impairment Questionnaire (WPAI), a 6-item questionnaire to measure work and activity impairment. Impairment due to a specified health problem during the past 7 days is reported, where higher scores indicate greater impact of health. Outcomes include percentage of work time missed (absenteeism), percentage of impairment while working (presenteeism), percentage of overall work impairment, and percentage of activity impairment due to health problems. The first 3 outcomes are calculated for persons who are working for pay, and the last outcome is calculated for all persons. In a clinical trial for IBD, the WPAI had adequate discriminative validity, reliability, and responsiveness [84]; it has good construct validity in RA [14], and it has been used in MS studies [15].

\section{Disease-Specific Measures}

The disease-specific measures were chosen to describe disease activity and disease progression or functional status. 
Table 1. Case identification (screening) instruments for depression and anxiety.

\begin{tabular}{|c|c|c|c|c|c|}
\hline Screening instruments for depression and anxiety & Construct & Number of items & Scoring & $\begin{array}{l}\text { Published } \\
\text { cut points }\end{array}$ & $\begin{array}{l}\text { Possible range } \\
\text { of values }\end{array}$ \\
\hline $\begin{array}{l}\text { Patient Health Questionnaire-brief (PHQ-2) [63] } \\
\text { (based on the first } 2 \text { questions in this scale) }\end{array}$ & Depression (presence of) & 2 & $\begin{array}{l}\text { Items scored 0-3, } \\
\text { summed }\end{array}$ & 3 & $0-6$ \\
\hline Patient Health Questionnaire (PHQ-9) [62] & Depression (presence of) & 9 & $\begin{array}{l}\text { Items scored } 0-3 \text {, } \\
\text { summed }\end{array}$ & 10 & $0-27$ \\
\hline Generalized Anxiety Disorder 7-Item Scale [64] & $\begin{array}{l}\text { Anxiety, generalized } \\
\text { (severity of) }\end{array}$ & 7 & $\begin{array}{l}\text { Items scored } 0-5 \text {, } \\
\text { summed }\end{array}$ & 10 & $0-21$ \\
\hline Overall Anxiety and Severity Impairment Scale [65] & Anxiety (severity of) & 5 & $\begin{array}{l}\text { Items scored } 0-4 \text {, } \\
\text { summed }\end{array}$ & 8 & $0-20$ \\
\hline Hospital Anxiety and Depression Scale [66] & $\begin{array}{l}\text { Depression (severity of), } \\
\text { anxiety (severity of) }\end{array}$ & $\begin{array}{l}14 \text { ( } 7 \text { for anxiety, } \\
7 \text { for depression) }\end{array}$ & $\begin{array}{l}\text { Items scored 0-3, } \\
\text { summed }\end{array}$ & 8,11 & $0-21$ \\
\hline Kessler-6 Distress Scale [67] & Nonspecific distress & 6 & $\begin{array}{l}\text { Items scored } 1-5 \text {, } \\
\text { summed }\end{array}$ & 19 & $\begin{array}{l}\text { 6-30 (alterna- } \\
\text { tive scoring) }\end{array}$ \\
\hline $\begin{array}{l}\text { National Institutes of Health Patient-Reported Out- } \\
\text { comes Measurement Information System-emotional } \\
\text { distress depression-Short Form 8a [68] }\end{array}$ & Depression (severity of) & 8 & $\begin{array}{l}\text { Items scored, } \\
\text { summed, and } \\
\text { then converted to } \\
\text { T score }\end{array}$ & T-score 60 & $\begin{array}{l}8-40, \mathrm{~T} \text { score } \\
38.2-81.3\end{array}$ \\
\hline $\begin{array}{l}\text { National Institutes of Health Patient-Reported Out- } \\
\text { comes Measurement Information System—emotional } \\
\text { distress anxiety—Short Form 8a [68] }\end{array}$ & Anxiety (severity of) & 8 & $\begin{array}{l}\text { Items scored, } \\
\text { summed, and } \\
\text { then converted to } \\
\text { T score }\end{array}$ & $\mathrm{T}$ score 60 & $\begin{array}{l}8-40, \mathrm{~T} \text { score } \\
37.1-83.1\end{array}$ \\
\hline
\end{tabular}

\section{Disease Activity}

We characterized disease activity using the Powell Tuck Index (PTI) for ulcerative colitis [85], the Harvey Bradshaw Disease Activity Index (HBDAI) for Crohn disease [86], annualized relapse rate for MS, and Clinical Disease Activity Index (CDAI) [87] for RA. The PTI and the HBDAI inquire about symptoms over the previous week and are administered by research staff. The HBDAI includes a score for the presence or absence of an abdominal mass as assessed by an abdominal exam conducted by trained personnel. A score of $\geq 5$ is considered active disease on each index. The CDAI is a composite obtained by summing 28 tender and 28 swollen joint counts and disease activity according to the patient (0-10) and the physician (0-10) [88]. It has the advantage of not requiring any laboratory tests. A score of 0-2.8 indicates remission, 2.9-10.0 indicates low activity, 10.1-22.0 indicates moderate activity, and 22.1-76.0 indicates high activity [89].

\section{Disease Progression}

Participants reported the year of symptom onset and the month and year of diagnosis of their IMID. Dates of symptom onset and diagnosis were verified using medical records. Current disease-modifying therapies were also captured from medical records. We characterized disease phenotype and progression in IBD using the Montreal Classification [31,90], which identifies 4 key variables in Crohn disease including age of onset, disease behavior (inflammatory, stricturing, or fistulizing disease), disease location (ileal only, colon only, small bowel and colon, and upper gastrointestinal tract), and whether perineal fistulas are present or not. In ulcerative colitis, the Montreal Classification identifies age of onset and extent of disease (either rectal, left-sided, or pancolitis). For MS, we used the Expanded Disability Status Scale (EDSS) [91], which is an ordinal measure of disability based on the neurological examination. Total EDSS scores range from 0 (no disability) to 10 (death due to MS), and are derived from scores on visual, brainstem, pyramidal, sensory, cerebellar, sphincter, and cerebral functional systems, as well as an observed walk of up to 500 meters. In RA, we used the modified Health Assessment Questionnaire (mHAQ) [92,93]. The mHAQ is a patient-reported measure that assesses functional status, specifically the degree of difficulty (without difficulty, 0; with some difficulty, 1; with much difficulty, 2; unable to do, 3) to perform 8 daily activities (dressing and grooming, arising, eating, walking, hygiene, reach, grip, and common daily activities). Responses are averaged to yield scores ranging from 0 to 3 . Where available, $\mathrm{x}$-rays obtained at annual clinic visits will be used to determine the presence of joint erosions.

\section{Sample Collection}

At the end of each assessment, consenting participants provided a blood sample collected by venipuncture using a straight needle into an EDTA tube and into a Paxgene (Qiagen) deoxyribonucleic acid (DNA) tube. Samples collected in EDTA tubes were centrifuged at $1500-2500 \times \mathrm{g}$ for $15 \mathrm{~min}$ at room temperature. The resulting plasma layer and buffy coat layers were aliquoted separately into $2 \mathrm{~mL}$ cyro vial tubes for storage at $-80^{\circ} \mathrm{C}$. DNA was extracted using a Paxgene DNA kit using a single tube procedure according to the manufacturer's (Qiagen) instructions and stored at $-80^{\circ} \mathrm{C}$.

\section{Data Management}

Study data were managed using REDCap electronic data capture tools hosted at the University of Manitoba [94]. REDCap (Research Electronic Data Capture) is a secure, Web-based application designed to support data capture for research studies, providing an intuitive interface for validated data entry, audit 
trails for tracking data manipulation and export procedures, automated export procedures for seamless data downloads to common statistical packages, and procedures for importing data from external sources [94].

\section{Sample Size}

The required sample size for the 2 principal aims was determined as follows. For the first aim, to test the baseline association between psychiatric comorbidity and either HRQOL or work disability in each IMID group, we assumed that at least $30 \%$ of the sample will experience any psychiatric comorbidity [95-97], confounders will explain $10 \%$ of the variation in the data, a 10\% difference in HRQOL (MCS-36/PCS-36), a 10-point difference in work impairment for the 2 psychiatric disorder (depression/anxiety) groups, a pooled standard deviation of 10 , and alpha=.05. For longitudinal analyses, we assumed an annual attrition rate of 3\% [98], an average annual rate of decline of $3 \%$ in HRQOL and work impairment, a pooled between-group variance of 10 , and a pooled within-group variance of 5. On the basis of these assumptions, each IMID and psychiatric group would need a minimum sample size of 150 , for a total of 750 .

For the second aim, which sought to test the performance of the case identification (screening) tools for depression and anxiety as compared with the SCID in the IMID groups, we assumed a lower bounds sensitivity $=0.75$ and specificity $\geq 0.85$ [62,99], precision $=0.15$, and alpha $=.05$, for which the required sample size per group was 247 . To detect a kappa $(\kappa)$ for agreement $\geq 0.60$ between the SCID and the screening tools, assuming alpha $=.05$, beta $=.20$, a null hypothesis of kappa $\geq .46$, and that depression or anxiety affects $\geq 15 \%$ of the IMID cohort, the required sample size per group was 250 .

Therefore, we sought to recruit 250 participants for each IMID group, and 150 each for the depression and anxiety disorder groups.

\section{Current Analysis}

We summarized the characteristics of the sample at enrollment for the purpose of assessing the potential generalizability of the findings. We summarized categorical variables using frequency (percentage) and continuous variables using mean (standard deviation) or median (25th-75th percentiles). Each of the disease groups was also reviewed relative to samples in other studies of those disease groups, to consider representativeness and generalizability of the samples. Statistical analyses were conducted using SAS V9.4 (SAS Institute Inc., Cary, NC).

\section{Future Analyses}

We will assess the impact of changes in psychiatric status on change in these HRQOL and work ability outcomes over the 4 measurement occasions (3-year period) using generalized linear models with generalized estimating equations to account for the dependence among the repeated measurements. We will select the distribution to model each outcome using a combination of empirical (eg, ratio of model deviation to its degrees of freedom) and theoretical considerations. We will choose a correlation structure for the repeated measurements by examining the pattern of empirical correlations. The independent variables of interest will be IMID type and psychiatric status. Psychiatric status will be determined based on the SCID-determined diagnoses (at enrollment) and symptom severity based on whichever screening instrument has the best performance characteristics (as described below). Potential confounding covariates will be age, sex, disease duration, education, smoking, body mass index, physical comorbidity, and disease activity status.

On the basis of published cut points, we will compare depression and anxiety status based on the SCID and the screening instruments using sensitivity, specificity, positive predictive value, and negative predictive value. We will also use receiver operating curve analysis to understand the relationship between sensitivity and the false positive rate, which allows an optimal cut point to be assigned depending on the requirements in a specific context. We will assess internal consistency reliability using Cronbach alpha [100]. In a subgroup of $\sim 150$ participants in each IMID group, we will determine the test-retest reliability of these instruments using an intraclass correlation coefficient.

\section{Results}

\section{Recruitment}

Between November 2014 and July 2016, we enrolled 982 individuals. Of these, 18 were later withdrawn; 6 did not meet inclusion criteria after review of their medical records because they did not have confirmed diagnoses of IBD (3) or RA (2), or had 2 of the IMID of interest (1). A total of 11 individuals enrolled as members of the psychiatric cohort were withdrawn as they did not have a confirmed diagnosis of depression or anxiety disorder following SCID administration. Finally, 1 individual in the IBD cohort withdrew from the study and that person's data were destroyed shortly after enrollment. Therefore, the final study population included 247 participants with IBD, 255 with MS, 154 with RA, and 308 with depression or anxiety (172 with depression, 136 with an anxiety disorder as self-identified at enrollment) for a total of 964. As expected, participants were recruited from multiple sources (Table 2). A higher proportion of participants with MS were recruited through targeted contacts, reflecting the delivery of MS care in Manitoba through a single specialty clinic, whereas care for other conditions is less centralized. 
Table 2. Recruitment sources for study participants.

\begin{tabular}{|c|c|c|c|c|}
\hline Source & $\begin{array}{l}\text { Inflammatory bowel disease } \\
(\mathrm{N}=247), \mathrm{n}(\%)\end{array}$ & $\begin{array}{l}\text { Multiple sclerosis } \\
(\mathrm{N}=255), \mathrm{n}(\%)\end{array}$ & $\begin{array}{l}\text { Rheumatoid arthritis } \\
(\mathrm{N}=154), \mathrm{n}(\%)\end{array}$ & $\begin{array}{l}\text { Depression/anxiety disorder } \\
(\mathrm{N}=308), \mathrm{n}(\%)\end{array}$ \\
\hline Targeted email/mail ${ }^{\mathrm{a}}$ & $98(39.7)$ & $222(87.0)$ & $52(33.8)$ & $59(19.1)$ \\
\hline Clinic/CBT class ${ }^{b}$ & $133(53.8)$ & $30(11.8)$ & $80(51.9)$ & $60(19.4)$ \\
\hline Poster (paper/electronic) & $5(2.0)$ & $3(1.2)$ & $10(6.5)$ & $60(19.4)$ \\
\hline Tweets/Facebook/Internet & $5(2.0)$ & $0(0)$ & $0(0)$ & $15(4.9)$ \\
\hline News article & $1(0.4)$ & $0(0)$ & $0(0)$ & $2(0.6)$ \\
\hline Clinician referral & $0(0)$ & $0(0)$ & $0(0)$ & $7(2.3)$ \\
\hline Word of mouth & $1(0.4)$ & $0(0)$ & $12(7.8)$ & $18(5.8)$ \\
\hline Unknown & $4(1.6)$ & $0(0)$ & $0(0)$ & $87(29.2)$ \\
\hline
\end{tabular}

${ }^{\mathrm{a}}$ Some participants in the MS Clinic registry were contacted by telephone rather than by mail.

${ }^{\mathrm{b}}$ Cognitive behavioral therapy (CBT) classes served as a recruitment source only for those with depression/anxiety.

Sociodemographic characteristics of the participants are shown in Table 3. Several differences were apparent across disease groups. The percentage of participants who were white varied across groups, being highest among those with IBD or MS and lowest among those with RA. We observed a female predominance in all groups, but this was least marked in the IBD cohort. Participants with depression or anxiety were more likely to be single than participants in any other group. Annual income also varied across groups, being highest in the IBD cohort.

\section{Individual Immune-Mediated Inflammatory Diseases Cohorts}

As has been observed in other IBD cohorts, participants were more likely to be females than males (Multimedia Appendix 1) [101-103]. The proportion of individuals reporting white background was higher in this study than that of a national US study [101], but lower than that seen in a previous Manitoba study [102]. The level of education was generally high, consistent with other studies [101-103]. Participants in the present MS cohort were older than those in 3 other Canadian MS study cohorts $[104,105]$, and a slightly higher proportion of females was observed also (Multimedia Appendix 2). The age at MS onset was slightly lower in this study than in the other cohorts. The proportion of female participants in the present RA cohort was higher than that reported in other RA cohorts, and the proportion with white ethnicity was lower (Multimedia Appendix 3) [106-108]. The second most common ethnicity in our cohort was First Nations and other Indigenous ethnicities (not specified).

The proportion of women in the depressed/anxiety disorder cohort was higher than that in a previous cohort from the Canadian Community Health Survey-Mental Health (CCHS) in 2012 (Multimedia Appendix 4). The percentage with more than a high school education level was similar in both cohorts. The proportion who smoked was lower in our cohort than in the CCHS cohort. 
Table 3. Cohort demographics stratified by disease group.

\begin{tabular}{|c|c|c|c|c|c|c|}
\hline Characteristics & Total $(\mathrm{N}=964)$ & $\begin{array}{l}\text { Inflammatory bowel } \\
\text { disease }(\mathrm{N}=247)\end{array}$ & $\begin{array}{l}\text { Multiple sclerosis } \\
(\mathrm{N}=255)\end{array}$ & $\begin{array}{l}\text { Rheumatoid } \\
\text { arthritis }(\mathrm{N}=154)\end{array}$ & $\begin{array}{l}\text { Depression/anxiety } \\
\text { disorder }(\mathrm{N}=308)\end{array}$ & $P$ value \\
\hline Age in years, mean $\left(\mathrm{SD}^{\mathrm{a}}\right)$ & $49.2(14.2)$ & $47.4(14.8)$ & $51.1(12.9)$ & $59.5(11.7)$ & $43.9(13.0)$ & \\
\hline Sex, $n(\%)$ & & & & & & $<.001$ \\
\hline Male & $235(24.4)$ & $92(37.2)$ & $47(18.4)$ & $24(15.6)$ & $72(23.5)$ & \\
\hline Female & 729 (75.6) & $155(62.7)$ & $208(81.6)$ & $130(84.4)$ & 235 (76.6) & \\
\hline \multicolumn{7}{|l|}{ Ethnicity, n (\%) } \\
\hline White & $786(81.9)$ & $210(85.4)$ & $217(85.4)$ & $114(74.5)$ & $245(79.8)$ & .01 \\
\hline Other & $174(18.1)$ & $36(14.6)$ & $37(14.5)$ & $39(25.5)$ & $62(20.2)$ & \\
\hline Missing & 4 & 1 & 1 & 1 & 1 & \\
\hline Education, n (\%) & & & & & & .06 \\
\hline Elementary school & $5(0.5)$ & $0(0)$ & $1(0.4)$ & $3(1.9)$ & $1(0.3)$ & \\
\hline Middle school & $44(4.5)$ & $8(3.2)$ & $9(3.5)$ & $11(7.1)$ & $16(5.2)$ & \\
\hline High school or GED ${ }^{b}$ & $268(27.8)$ & $68(27.5)$ & $78(30.6)$ & $37(24.0)$ & $85(27.6)$ & \\
\hline College & $253(26.2)$ & $51(20.6)$ & $72(28.2)$ & $45(29.2)$ & $85(27.6)$ & \\
\hline Technical or trade & $107(11.1)$ & $32(13.0)$ & $29(11.4)$ & $19(12.3)$ & $27(8.8)$ & \\
\hline Bachelor's degree & $215(22.3)$ & $60(24.3)$ & $56(22.0)$ & $27(17.5)$ & $72(23.4)$ & \\
\hline Master's degree & $54(5.6)$ & $21(8.5)$ & $7(2.8)$ & $10(6.5)$ & $16(5.2)$ & \\
\hline Doctoral degree & $18(1.9)$ & $7(2.8)$ & $3(1.2)$ & $2(1.3)$ & $6(1.9)$ & \\
\hline Annual income, n (\%) & & & & & & $<.001$ \\
\hline Less than Can $\$ 15,000$ & $100(10.4)$ & $14(5.7)$ & $20(7.8)$ & $19(12.3)$ & $47(15.3)$ & \\
\hline Can $\$ 15,000-29,999$ & $88(9.1)$ & $14(5.7)$ & $24(9.4)$ & $19(12.3)$ & $31(10.1)$ & \\
\hline Can $\$ 30,000-49,999$ & $162(16.8)$ & $29(11.7)$ & $37(14.5)$ & $32(20.8)$ & $64(20.8)$ & \\
\hline Can $\$ 50,000-100,000$ & $341(35.4)$ & $104(42.1)$ & $99(38.8)$ & $48(31.2)$ & $90(29.2)$ & \\
\hline More than Can $\$ 100,000$ & $189(19.6)$ & $68(27.5)$ & $47(18.4)$ & $25(16.2)$ & 49 (15.9) & \\
\hline I do not wish to answer & $84(8.7)$ & $18(7.3)$ & $28(11.0)$ & $11(7.1)$ & $27(8.8)$ & \\
\hline Marital status, n (\%) & & & & & & $<.001$ \\
\hline Single or never married & $217(22.5)$ & $56(22.7)$ & $30(11.8)$ & $20(13.0)$ & $111(36.0)$ & \\
\hline Married or common law & $569(59.0)$ & $160(64.8)$ & $182(71.4)$ & $93(60.4)$ & $134(43.5)$ & \\
\hline Divorced or separated & $150(15.6)$ & $24(9.7)$ & $39(15.3)$ & $31(20.1)$ & $56(18.2)$ & \\
\hline Widowed & $28(2.9)$ & $7(2.8)$ & $4(1.6)$ & $10(6.5)$ & $7(2.3)$ & \\
\hline
\end{tabular}

${ }^{\mathrm{a}} \mathrm{SD}$ : standard deviation.

${ }^{\mathrm{b}}$ GED: General Education Diploma.

\section{Discussion}

This paper presents the study rationale, describes study procedures, and characterizes the cohort enrolled. The ultimate goal of the study was to compare and contrast the impact of psychiatric comorbidity on outcomes in IMID that affect different organ systems but share the issues of immune dysregulation and inflammation. We hope to gain more specific insights into the role of psychiatric comorbidity in IMID, with the aim of improved care for individuals affected by IMID. These analyses will be conducted once the cohort completes follow-up.
When selecting the measures for this study, we sought standardized measures appropriate for the domains of interest. Where possible, we chose instruments with good criterion and construct validity, and high reliability, which had been demonstrated in one or more of the disease groups of interest. If this was not possible, we favored validated measures used in Canadian national data collection efforts to offer the opportunity for comparisons of this cohort with national cohorts.

\section{Participants}

Our recruitment strategy precluded the determination of a participation rate, as it was designed to reach potential participants from a broad range of settings using general and 
targeted strategies. For all of the groups except for the RA group, we were able to recruit the desired number of participants; the time period for recruitment was limited by the need to complete 3 years of follow-up by the end of the funding period. It has been noted that participation rates in cohort studies and surveys have declined over the last 3 decades [109]. Several factors have been suggested to contribute to this decline [109]. These include an increasing array of research and marketing studies, a decrease in volunteerism, and the complexity of study demands. The latter is likely to be a particular issue in our study given the length of study visits, which range from 1.5 to 3 hours depending on the disease group, and the requested duration of participation (3 years). Nonetheless, our sample size remains large enough to meet the study's main objectives.

Retention of study participants will be critical, and we aimed to minimize attribution by employing several strategies that have been successful in other studies [110,111]. First, participants are offered gift cards to recognize their contributions to the study at each study visit as this has been shown to improve response rates [112]. Second, retention is carefully tracked. All participants receive reminder phone calls or emails for study appointments depending on their preference. Study coordinators are flexible about rescheduling appointments and follow-up with all participants who miss appointments. Third, a study newsletter is distributed semiannually. The newsletter provides information about study team members, progress, and findings, as well as information about relevant research news and wellness. We hope that annual face-to-face contact will also aid retention. Finally, when participants move out of province or become too ill to attend study visits, they are offered the opportunity to maintain participation by completing some of the study assessments such as questionnaires by telephone or mail.

The characteristics of participants enrolled in our study are similar to those enrolled in other studies after accounting for differences in how variables were measured, supporting the representativeness of the sample across the disease groups. However, some differences with respect to other cohorts and the general IMID populations of interest are worth noting. Participants in the MS cohort were older than those in some other cohorts, likely reflecting recruitment efforts aimed at capturing the full spectrum of individuals with MS. The proportion of participants with MS who were women was slightly higher than expected, even when considering that women are affected by MS two to three times more often than men [113]. Similarly, the proportion of individuals with RA or depression/anxiety disorder who were women was also somewhat higher than expected. The proportion of individuals reporting white race/ethnicity was lower in our RA cohort than that observed in other cohorts, but this may better reflect the local demographics, as there is a large First Nations (Indigenous) population in Manitoba [114], and there is a high risk of RA in this group. There was a very high proportion of participants with RA who were actively being treated with disease-modifying antirheumatic drugs, potentially reflecting oversampling of participants from a tertiary care center relative to community sampling. The level of education in all recruited cohorts was relatively high.

\section{Limitations}

Selection bias is a potential limitation of any study. As reviewed elsewhere [109], certain demographic characteristics are associated with participation in research. Women are more likely to participate in research studies than men. Findings regarding age are inconsistent, as are findings regarding race/ethnicity. Individuals with higher levels of education and higher socioeconomic status are more likely to participate. However, in studies focused on a particular health condition or exposure, health status and relevance of the study subject to the potential participant also influence participation and may modify these demographic patterns [109].

In addition to potential selection biases, attrition may occur despite the use of appropriate retention strategies due to death, loss to follow-up, or other reasons. As noted, we did not achieve the desired sample size for the RA cohort, and this will reduce statistical power for RA-specific analyses. To minimize participant burden, we included only a single measure of pain and of fatigue, although these are multidimensional concepts that may be better evaluated with multiple instruments that capture different dimensions. We did not capture all potential confounders such as the life events (eg, pregnancy, menopause) that may be unique to subgroups of the study population and that may be associated with disease activity and psychiatric status in IMID [115-117].

\section{Conclusions}

Nonetheless, this study has several strengths including the establishment of representative cohorts of those with IMID and depression and anxiety disorders, which will support comparative work, as well as careful attention to retention and stakeholder engagement. We expect this comprehensive prospective longitudinal study to provide valuable new knowledge about the impact of psychiatric comorbidity on IMID, including on outcomes important to affected individuals and society, such as HRQOL and work disability. We also expect that this study will contribute to improved diagnosis of psychiatric comorbidity by identifying validated instruments which can be used in clinical practice. For health care providers, an understanding of the relationships between psychiatric disorders, symptoms of pain, and fatigue and outcomes should encourage more attention to the identification and treatment of psychiatric disorders and change the approach to disease management to improve outcomes in IMID. The analytical methods used will support future research regarding patient-reported outcome measures. Focusing on three IMID with similarities and differences will support the generalizability of our findings to other IMID and provide policy makers with the evidence base to make decisions regarding health services for IMID broadly. 


\section{Acknowledgments}

This study was funded by the Canadian Institutes of Health Research (THC-135234), Crohn's and Colitis Canada, and the Waugh Family Chair in Multiple Sclerosis (to RAM). Dr Bernstein is supported in part by the Bingham Chair in Gastroenterology. Dr Sareen is supported by CIHR \#333252. Dr Katz is supported by Research Manitoba and the Health and Stroke Foundation through the Manitoba Chair in Primary Prevention Research. Dr Lix is supported by a Research Manitoba Chair. Dr Zarychanski is supported by a CIHR New Investigator Salary Award. The sponsors had no role in the design and conduct of the study, collection and interpretation of the data, or in the decision to submit the manuscript for publication.

Members of the CIHR Team in Defining the Burden and Managing the Effects of Psychiatric Comorbidity in Chronic Immunoinflammatory Disease are as follows: RAM, JB, JS, JRW, SBP, AS, LML, CAH, RE-G, AK, JDF, CNB, LG, LIB, RZ, $\mathrm{CAP}$, and JM.

\section{Conflicts of Interest}

RAM has conducted clinical trials for Sanofi Aventis. CAH has research funds for unrelated studies from UCB Canada. JS holds stocks in Johnson and Johnson. CNB has consulted Abbvie Canada, Ferring Canada, Janssen Canada, Pfizer Canada, Shire Canada, Takeda Canada, and Napo Pharmaceuticals and has consulted Mylan Pharmaceuticals. He has received unrestricted educational grants from Abbvie Canada, Janssen Canada, Shire Canada, and Takeda Canada. He has been on speaker's bureau of Abbvie Canada, Ferring Canada, and Shire Canada. All other authors have no conflicts of interest to declare.

\section{Multimedia Appendix 1}

Characteristics of participants with inflammatory bowel disease (IBD) and those of participants in other IBD cohorts.

[PDF File (Adobe PDF File), 30KB-Multimedia Appendix 1]

\section{Multimedia Appendix 2}

Characteristics of participants with multiple sclerosis (MS) and those of participants in other Canadian MS studies.

[PDF File (Adobe PDF File), 26KB-Multimedia Appendix 2]

\section{Multimedia Appendix 3}

Characteristics of participants with rheumatoid arthritis (RA) and those of participants in other RA cohorts.

[PDF File (Adobe PDF File), 30KB-Multimedia Appendix 3]

\section{Multimedia Appendix 4}

Characteristics of participants with depression or anxiety disorder and those of participants in other depression or anxiety disorder cohorts.

[PDF File (Adobe PDF File), 25KB-Multimedia Appendix 4]

\section{References}

1. Kobelt G, Berg J, Atherly D, Hadjimichael O. Costs and quality of life in multiple sclerosis: a cross-sectional study in the United States. Neurology 2006 Jun 13;66(11):1696-1702. [doi: 10.1212/01.wnl.0000218309.01322.5c] [Medline: 16769943]

2. Kappelman MD, Rifas-Shiman SL, Porter CQ, Ollendorf DA, Sandler RS, Galanko JA, et al. Direct health care costs of Crohn's disease and ulcerative colitis in US children and adults. Gastroenterology 2008 Dec;135(6):1907-1913 [FREE Full text] [doi: 10.1053/j.gastro.2008.09.012] [Medline: 18854185]

3. Canadian Institute for Health Information. Cpa.ca. 2007. The burden of neurological diseases, disorders and injuries in Canada URL: http://www.cpa.ca/cpasite/UserFiles/Documents/Practice Page/Burden neuro diseases en.pdf [accessed 2018-01-10] [WebCite Cache ID 6wMcz6JD6]

4. Health Canada. Arthritis in Canada: An ongoing challenge. Acreu.ca 2003 [FREE Full text]

5. Hermann BP, Vickrey B, Hays RD, Cramer J, Devinsky O, Meador K, et al. A comparison of health-related quality of life in patients with epilepsy, diabetes and multiple sclerosis. Epilepsy Res 1996 Oct;25(2):113-118. [Medline: $\underline{8884169]}$

6. Nortvedt MW, Riise T, Myhr KM, Nyland HI. Quality of life in multiple sclerosis: measuring the disease effects more broadly. Neurology 1999 Sep 22;53(5):1098-1103. [Medline: 10496273]

7. Rudick RA, Miller D, Clough JD, Gragg LA, Farmer RG. Quality of life in multiple sclerosis. Comparison with inflammatory bowel disease and rheumatoid arthritis. Arch Neurol 1992 Dec;49(12):1237-1242. [Medline: 1449401]

8. Lankhorst GJ, Jelles F, Smits RC, Polman CH, Kuik DJ, Pfennings LE, et al. Quality of life in multiple sclerosis: the disability and impact profile (DIP). J Neurol 1996 Jun;243(6):469-474. [Medline: 8803821$]$ 
9. Høivik ML, Moum B, Solberg IC, Henriksen M, Cvancarova M, Bernklev T, IBSEN Group. Work disability in inflammatory bowel disease patients 10 years after disease onset: results from the IBSEN Study. Gut 2013 Mar;62(3):368-375. [doi: 10.1136/gutjnl-2012-302311] [Medline: 22717453]

10. Wolfe F, Hawley DJ. The longterm outcomes of rheumatoid arthritis: Work disability: a prospective 18 year study of 823 patients. J Rheumatol 1998 Nov;25(11):2108-2117. [Medline: 9818651]

11. Simmons RD, Tribe KL, McDonald EA. Living with multiple sclerosis: longitudinal changes in employment and the importance of symptom management. J Neurol 2010 Jun;257(6):926-936. [doi: 10.1007/s00415-009-5441-7] [Medline: 20084515]

12. Rapaport MH, Clary C, Fayyad R, Endicott J. Quality-of-life impairment in depressive and anxiety disorders. Am J Psychiatry 2005 Jun;162(6):1171-1178. [doi: 10.1176/appi.ajp.162.6.1171] [Medline: 15930066]

13. Stein MB, Roy-Byrne PP, Craske MG, Bystritsky A, Sullivan G, Pyne JM, et al. Functional impact and health utility of anxiety disorders in primary care outpatients. Med Care 2005 Dec;43(12):1164-1170. [Medline: 16299426]

14. Zhang W, Bansback N, Boonen A, Young A, Singh A, Anis AH. Validity of the work productivity and activity impairment questionnaire--general health version in patients with rheumatoid arthritis. Arthritis Res Ther 2010;12(5):R177 [FREE Full text] [doi: 10.1186/ar3141] [Medline: 20860837]

15. Glanz BI, Dégano IR, Rintell DJ, Chitnis T, Weiner HL, Healy BC. Work productivity in relapsing multiple sclerosis: associations with disability, depression, fatigue, anxiety, cognition, and health-related quality of life. Value Health 2012 Dec;15(8):1029-1035 [FREE Full text] [doi: 10.1016/j.jval.2012.07.010] [Medline: 23244804]

16. Bansback N, Zhang W, Walsh D, Kiely P, Williams R, Guh D, et al. Factors associated with absenteeism, presenteeism and activity impairment in patients in the first years of RA. Rheumatology (Oxford) 2012 Feb;51(2):375-384. [doi: 10.1093/rheumatology/ker385] [Medline: 22179728]

17. Gulick EE. Emotional distress and activities of daily living functioning in persons with multiple sclerosis. Nurs Res 2001;50(3):147-154. [Medline: 11393636]

18. Irwin M, Miller A. Depressive disorders and immunity: 20 years of progress and discovery. Brain Behav Immun 2007 May;21(4):374-383. [doi: 10.1016/j.bbi.2007.01.010] [Medline: 17360153]

19. Hankin BL. Future directions in vulnerability to depression among youth: integrating risk factors and processes across multiple levels of analysis. J Clin Child Adolesc Psychol 2012;41(5):695-718 [FREE Full text] [doi: 10.1080/15374416.2012.711708] [Medline: 22900513]

20. Maddock C, Pariante CM. How does stress affect you? An overview of stress, immunity, depression and disease. Epidemiol Psichiatr Soc 2001;10(3):153-162. [Medline: 11787449]

21. Patten SB. Major depression epidemiology from a diathesis-stress conceptualization. BMC Psychiatry 2013 Jan 11;13:19 [FREE Full text] [doi: 10.1186/1471-244X-13-19] [Medline: 23305517]

22. McGuigan C, Hutchinson M. Unrecognised symptoms of depression in a community-based population with multiple sclerosis. J Neurol 2006 Feb;253(2):219-223. [doi: 10.1007/s00415-005-0963-0] [Medline: 16177840]

23. Marrie RA, Horwitz R, Cutter G, Tyry T, Campagnolo D, Vollmer T. The burden of mental comorbidity in multiple sclerosis: frequent, underdiagnosed, and undertreated. Mult Scler 2009 Mar;15(3):385-392. [doi: 10.1177/1352458508099477] [Medline: 19153176 ]

24. Mohr DC, Hart SL, Fonareva I, Tasch ES. Treatment of depression for patients with multiple sclerosis in neurology clinics. Mult Scler 2006 Apr;12(2):204-208. [doi: 10.1191/135248506ms1265oa] [Medline: 16629424]

25. Hider SL, Tanveer W, Brownfield A, Mattey DL, Packham JC. Depression in RA patients treated with anti-TNF is common and under-recognized in the rheumatology clinic. Rheumatology (Oxford) 2009 Sep;48(9):1152-1154. [doi: 10.1093/rheumatology/kep170] [Medline: 19608723]

26. Bennebroek EF, Thijssens NA, Stokkers PC, Grootenhuis MA, Bockting CL, Nieuwkerk PT, et al. Do inflammatory bowel disease patients with anxiety and depressive symptoms receive the care they need? J Crohns Colitis 2012 Feb;6(1):68-76. [doi: 10.1016/j.crohns.2011.07.006] [Medline: 22261530]

27. Pincus T, Hassett AL, Callahan LF. Criterion contamination of depression scales in patients with rheumatoid arthritis: the need for interpretation of patient questionnaires (as all clinical measures) in the context of all information about the patient. Rheum Dis Clin North Am 2009 Nov;35(4):861-4, xi-xii. [doi: 10.1016/j.rdc.2009.10.015] [Medline: 19962630]

28. Litster B, Fiest KM, Patten SB, Fisk JD, Walker JR, Graff LA, CIHR Team "Defining the Burden and Managing the Effects of Psychiatric Comorbidity in Chronic Immunoinflammatory Disease". Screening tools for anxiety in people with multiple sclerosis: a systematic review. Int J MS Care 2016;18(6):273-281 [FREE Full text] [doi: 10.7224/1537-2073.2016-004] [Medline: 27999521]

29. Hind D, Kaklamanou D, Beever D, Webster R, Lee E, Barkham M, et al. The assessment of depression in people with multiple sclerosis: a systematic review of psychometric validation studies. BMC Psychiatry 2016 Aug 4;16:278 [FREE Full text] [doi: 10.1186/s12888-016-0931-5] [Medline: 27491674]

30. Suárez-Mendoza AA, Cardiel MH, Caballero-Uribe CV, Ortega-Soto HA, Márquez-Marín M. Measurement of depression in Mexican patients with rheumatoid arthritis: validity of the Beck Depression Inventory. Arthritis Care Res 1997 Jun;10(3):194-199. [Medline: 9335631] 
31. Silverberg MS, Satsangi J, Ahmad T, Arnott ID, Bernstein CN, Brant SR, et al. Toward an integrated clinical, molecular and serological classification of inflammatory bowel disease: report of a Working Party of the 2005 Montreal World Congress of Gastroenterology. Can J Gastroenterol 2005 Sep;19 Suppl A:5A-36A. [Medline: 16151544]

32. Bernstein CN. On making the diagnosis of ulcerative colitis. Am J Gastroenterol 1997 Aug;92(8):1247-1252. [Medline: 9260783]

33. McDonald WI, Compston A, Edan G, Goodkin D, Hartung HP, Lublin FD, et al. Recommended diagnostic criteria for multiple sclerosis: guidelines from the international panel on the diagnosis of multiple sclerosis. Ann Neurol 2001 Jul;50(1):121-127. [Medline: 11456302]

34. Poser CM, Paty DW, Scheinberg L, McDonald WI, Davis FA, Ebers GC, et al. New diagnostic criteria for multiple sclerosis: guidelines for research protocols. Ann Neurol 1983 Mar;13(3):227-231. [doi: 10.1002/ana.410130302] [Medline: 6847134]

35. Polman CH, Reingold SC, Banwell B, Clanet M, Cohen JA, Filippi M, et al. Diagnostic criteria for multiple sclerosis: 2010 revisions to the McDonald criteria. Ann Neurol 2011 Feb;69(2):292-302 [FREE Full text] [doi: 10.1002/ana.22366] [Medline: 21387374]

36. Polman CH, Reingold SC, Edan G, Filippi M, Hartung H, Kappos L, et al. Diagnostic criteria for multiple sclerosis: 2005 revisions to the "McDonald Criteria". Ann Neurol 2005 Dec;58(6):840-846. [doi: 10.1002/ana.20703] [Medline: 16283615]

37. Aletaha D, Neogi T, Silman AJ, Funovits J, Felson DT, Bingham 3rd CO, et al. 2010 Rheumatoid arthritis classification criteria: an American College of Rheumatology/European League Against Rheumatism collaborative initiative. Arthritis Rheum 2010 Sep;62(9):2569-2581 [FREE Full text] [doi: 10.1002/art.27584] [Medline: 20872595]

38. Diagnostic and Statistical Manual of Mental Disorders, Fourth Edition. Washington, DC: American Psychiatric Association; 2000.

39. Bernstein CN, Blanchard JF, Rawsthorne P, Wajda A. Epidemiology of Crohn's disease and ulcerative colitis in a central Canadian province: a population-based study. Am J Epidemiol 1999 May 15;149(10):916-924. [Medline: 10342800]

40. Noc.esdc.gc.ca. Ottawa: Government of Canada; 2017. National Occupational Classification - Resources \& Tools URL: http://noc.esdc.gc.ca/English/home.aspx [accessed 2017-10-14] [WebCite Cache ID 6uDVRn8Tf]

41. Cutter GR, Baier ML, Rudick RA, Cookfair DL, Fischer JS, Petkau J, et al. Development of a multiple sclerosis functional composite as a clinical trial outcome measure. Brain 1999 May;122 (Pt 5):871-882. [Medline: 10355672]

42. Fischer JS, Jak AJ, Kniker JE, Rudick RA, Cutter G. Nationalmssociety. 2001. Multiple Sclerosis Functional Composite (MSFC) URL: https://www.nationalmssociety.org/NationalMSSociety/media/MSNationalFiles/Brochures/

10-2-3-31-MSFC Manual and Forms.pdf [accessed 2018-01-12] [WebCite Cache ID 6wP17Klco]

43. Fischer JS, Rudick RA, Cutter GR, Reingold SC. The Multiple Sclerosis Functional Composite Measure (MSFC): an integrated approach to MS clinical outcome assessment. National MS Society Clinical Outcomes Assessment Task Force. Mult Scler 1999 Aug;5(4):244-250. [doi: 10.1177/135245859900500409] [Medline: 10467383]

44. Bohannon RW. Comfortable and maximum walking speed of adults aged 20-79 years: reference values and determinants. Age Ageing 1997 Jan;26(1):15-19. [Medline: 9143432]

45. Peel NM, Kuys SS, Klein K. Gait speed as a measure in geriatric assessment in clinical settings: a systematic review. J Gerontol A Biol Sci Med Sci 2013 Jan;68(1):39-46. [doi: 10.1093/gerona/gls174] [Medline: 22923430]

46. Poole JL. Measures of hand function: Arthritis Hand Function Test (AHFT), Australian Canadian Osteoarthritis Hand Index (AUSCAN), Cochin Hand Function Scale, Functional Index for Hand Osteoarthritis (FIHOA), Grip Ability Test (GAT), Jebsen Hand Function Test (JHFT), and Michigan Hand Outcomes Questionnaire (MHQ). Arthritis Care Res (Hoboken) 2011 Nov;63 Suppl 11:S189-S199 [FREE Full text] [doi: 10.1002/acr.20631] [Medline: 22588744]

47. Chiaravalloti ND, DeLuca J. Cognitive impairment in multiple sclerosis. Lancet Neurol 2008 Dec;7(12):1139-1151. [doi: 10.1016/S1474-4422(08)70259-X] [Medline: $\underline{19007738]}$

48. Shin SY, Katz P, Wallhagen M, Julian L. Cognitive impairment in persons with rheumatoid arthritis. Arthritis Care Res (Hoboken) 2012 Aug;64(8):1144-1150 [FREE Full text] [doi: 10.1002/acr.21683] [Medline: 22505279]

49. van Langenberg DR, Yelland GW, Robinson SR, Gibson PR. Cognitive impairment in Crohn's disease is associated with systemic inflammation, symptom burden and sleep disturbance. United European Gastroenterol J 2017 Jun;5(4):579-587 [FREE Full text] [doi: 10.1177/2050640616663397] [Medline: 28588890]

50. Millan MJ, Agid Y, Brüne M, Bullmore ET, Carter CS, Clayton NS, et al. Cognitive dysfunction in psychiatric disorders: characteristics, causes and the quest for improved therapy. Nat Rev Drug Discov 2012 Feb 1;11(2):141-168. [doi: 10.1038/nrd3628] [Medline: 22293568]

51. Smith A. Symbol Digit Modalities Test, 9th edition. Los Angeles: Western Psychological Services; 2002.

52. Wechsler D. Wechsler Memory Scale-Third Edition. San Antonio, TX: The Psychological Corporation; 1997.

53. Delis DC, Kramer JH, Kaplan E, Ober BA. California Verbal Learning Test Second Edition Adult Version Manual. San Antonio, TX: The Psychological Corporation; 2000.

54. Oakland T, Glutting J, Horton C. The Wechsler Test of Adult Reading (WTAR). San Antonio, TX: The Psychological Corporation; 2001.

55. Mitra M, Chung M, Wilber N, Klein WD. Smoking status and quality of life: a longitudinal study among adults with disabilities. Am J Prev Med 2004 Oct;27(3):258-260. [doi: 10.1016/j.amepre.2004.06.002] [Medline: 15450640] 
56. Dickerson F, Schroeder J, Katsafanas E, Khushalani S, Origoni AE, Savage C, et al. Cigarette smoking by patients with serious mental illness, 1999-2016: an increasing disparity. Psychiatr Serv 2017 Sep 15:appips201700118. [doi: 10.1176/appi.ps.201700118] [Medline: 28945183]

57. Weinberger AH, Kashan RS, Shpigel DM, Esan H, Taha F, Lee CJ, et al. Depression and cigarette smoking behavior: a critical review of population-based studies. Am J Drug Alcohol Abuse 2016 Jun 10;43(4):416-431. [doi: 10.3109/00952990.2016.1171327]

58. Grant BF, Hasin DS, Chou SP, Stinson FS, Dawson DA. Nicotine dependence and psychiatric disorders in the United States: results from the national epidemiologic survey on alcohol and related conditions. Arch Gen Psychiatry 2004 Nov;61(11):1107-1115. [doi: 10.1001/archpsyc.61.11.1107] [Medline: 15520358]

59. Sangha O, Stucki G, Liang MH, Fossel AH, Katz JN. The Self-Administered Comorbidity Questionnaire: a new method to assess comorbidity for clinical and health services research. Arthritis Rheum 2003 Apr 15;49(2):156-163 [FREE Full text] [doi: 10.1002/art.10993] [Medline: 12687505]

60. Horton M, Rudick RA, Hara-Cleaver C, Marrie RA. Validation of a self-report comorbidity questionnaire for multiple sclerosis. Neuroepidemiology 2010 Aug;35(2):83-90. [Medline: 20551692]

61. First MB, Gibbon M, Spitzer RL, Williams JB. Scid4. New York, NY: Biometrics Research Department, New York State Psychiatric Institute; 2002. User's Guide for the Structured Clinical Interview for DSM-IV-TR Axis I Disorders - Research Version - (SCID-I for DSM-IV-TR, November 2002 Revision) URL: http://www.scid4.org/faq/research version.html [accessed 2018-01-12] [WebCite Cache ID 6wPk48uVH]

62. Spitzer RL, Kroenke K, Williams JB. Validation and utility of a self-report version of PRIME-MD: the PHQ primary care study. Primary Care Evaluation of Mental Disorders. Patient Health Questionnaire. J Am Med Assoc 1999 Nov 10;282(18):1737-1744. [Medline: $\underline{10568646]}$

63. Kroenke K, Spitzer RL, Williams JB. The Patient Health Questionnaire-2: validity of a two-item depression screener. Med Care 2003 Nov;41(11):1284-1292. [doi: 10.1097/01.MLR.0000093487.78664.3C] [Medline: 14583691]

64. Spitzer RL, Kroenke K, Williams JB, Löwe B. A brief measure for assessing generalized anxiety disorder: the GAD-7. Arch Intern Med 2006 May 22;166(10):1092-1097. [doi: 10.1001/archinte.166.10.1092] [Medline: 16717171]

65. Norman SB, Cissell SH, Means-Christensen AJ, Stein MB. Development and validation of an Overall Anxiety Severity And Impairment Scale (OASIS). Depress Anxiety 2006;23(4):245-249. [doi: 10.1002/da.20182] [Medline: 16688739]

66. Zigmond AS, Snaith RP. The hospital anxiety and depression scale. Acta Psychiatr Scand 1983 Jun;67(6):361-370. [Medline: $\underline{6880820]}$

67. Kessler RC, Barker PR, Colpe LJ, Epstein JF, Gfroerer JC, Hiripi E, et al. Screening for serious mental illness in the general population. Arch Gen Psychiatry 2003 Feb;60(2):184-189. [Medline: 12578436]

68. Pilkonis PA, Choi SW, Reise SP, Stover AM, Riley WT, Cella D, PROMIS Cooperative Group. Item banks for measuring emotional distress from the Patient-Reported Outcomes Measurement Information System (PROMIS®): depression, anxiety, and anger. Assessment 2011 Sep;18(3):263-283 [FREE Full text] [doi: 10.1177/1073191111411667] [Medline: 21697139]

69. Arroll B, Goodyear-Smith F, Kerse N, Fishman T, Gunn J. Effect of the addition of a "help" question to two screening questions on specificity for diagnosis of depression in general practice: diagnostic validity study. BMJ 2005 Oct 15;331(7521):884. [doi: 10.1136/bmj.38607.464537.7C] [Medline: 16166106 ]

70. Cohen S, Kamarck T, Mermelstein R. A global measure of perceived stress. J Health Soc Behav 1983 Dec;24(4):385-396. [Medline: 6668417]

71. Cohen S, Doyle WJ, Skoner DP. Psychological stress, cytokine production, and severity of upper respiratory illness. Psychosom Med 1999;61(2):175-180. [Medline: 10204970]

72. Lesage FX, Berjot S, Deschamps F. Psychometric properties of the French versions of the Perceived Stress Scale. Int J Occup Med Environ Health 2012 Jun;25(2):178-184 [FREE Full text] [doi: 10.2478/S13382-012-0024-8] [Medline: 22528542]

73. Leung DY, Lam TH, Chan SS. Three versions of Perceived Stress Scale: validation in a sample of Chinese cardiac patients who smoke. BMC Public Health 2010 Aug 25;10:513. [Medline: 20735860]

74. Andreou E, Alexopoulos EC, Lionis C, Varvogli L, Gnardellis C, Chrousos GP, et al. Perceived Stress Scale: reliability and validity study in Greece. Int J Environ Res Public Health 2011 Aug;8(8):3287-3298. [Medline: 21909307]

75. Stewart AL, Ware Jr JE, editors. Measuring Functioning and Well-Being: The Medical Outcomes Study Approach. Durham, NC: Duke University Press; 1992.

76. Ritvo PG, Fischer JS, Miller DM, Andrews H, Paty DW, LaRocca NG. Multiple Sclerosis Quality of Life Inventory: A User's Manual. New York, NY: National Multiple Sclerosis Society; 1997.

77. Ritvo PG, Fischer JS, Miller DM, Andrews H, Paty DW, LaRocca NG. Multiple Sclerosis Quality of Life Inventory: Technical Supplement. New York, NY: National Multiple Sclerosis Society; 1997.

78. Fisk JD, Doble SE. Construction and validation of a fatigue impact scale for daily administration (D-FIS). Qual Life Res 2002 May;11(3):263-272. [Medline: 12074263]

79. Benito-Leon J, Martinez-Martin P, Frades B, Martinez-Gines M, de Andreas C, Meca-Lallana JE, et al. Impact of fatigue in multiple sclerosis: the Fatigue Impact Scale for Daily Use (D-FIS). Mult Scler 2007 Jun;13(5):645-651. [Medline: $\underline{17548445]}$ 
80. McHorney CA, Ware Jr JE, Raczek AE. The MOS 36-Item Short-Form Health Survey (SF-36): II. Psychometric and clinical tests of validity in measuring physical and mental health constructs. Med Care 1993 Mar;31(3):247-263. [Medline: 8450681$]$

81. Nortvedt MW, Riise T, Myhr KM, Nyland HI. Performance of the SF-36, SF-12, and RAND-36 summary scales in a multiple sclerosis population. Med Care 2000 Oct;38(10):1022-1028. [Medline: 11021675]

82. Bernklev T, Jahnsen J, Lygren I, Henriksen M, Vatn M, Moum B. Health-related quality of life in patients with inflammatory bowel disease measured with the short form-36: psychometric assessments and a comparison with general population norms. Inflamm Bowel Dis 2005 Oct;11(10):909-918. [Medline: 16189421]

83. Linde L, Sørensen J, Ostergaard M, Hørslev-Petersen K, Hetland ML. Health-related quality of life: validity, reliability, and responsiveness of SF-36, 15D, EQ-5D [corrected] RAQoL, and HAQ in patients with rheumatoid arthritis. J Rheumatol 2008 Aug;35(8):1528-1537. [Medline: 18484697]

84. Reilly MC, Gerlier L, Brabant Y, Brown M. Validity, reliability, and responsiveness of the work productivity and activity impairment questionnaire in Crohn's disease. Clin Ther 2008 Feb;30(2):393-404. [doi: 10.1016/j.clinthera.2008.02.016] [Medline: 18343277$]$

85. Powell-Tuck J, Bown RL, Lennard-Jones JE. A comparison of oral prednisolone given as single or multiple daily doses for active proctocolitis. Scand J Gastroenterol 1978;13(7):833-837. [Medline: 364626]

86. Harvey RF, Bradshaw JM. A simple index of Crohn's-disease activity. Lancet 1980 Mar 8;1(8167):514. [Medline: 6102236]

87. Anderson J, Caplan L, Yazdany J, Robbins ML, Neogi T, Michaud K, et al. Rheumatoid arthritis disease activity measures: American College of Rheumatology recommendations for use in clinical practice. Arthritis Care Res (Hoboken) 2012 May;64(5):640-647 [FREE Full text] [doi: 10.1002/acr.21649] [Medline: 22473918]

88. Aletaha D, Nell VP, Stamm T, Uffmann M, Pflugbeil S, Machold K, et al. Acute phase reactants add little to composite disease activity indices for rheumatoid arthritis: validation of a clinical activity score. Arthritis Res Ther 2005;7(4):R796-R806 [FREE Full text] [doi: 10.1186/ar1740] [Medline: 15987481]

89. Anderson JK, Zimmerman L, Caplan L, Michaud K. Measures of rheumatoid arthritis disease activity: Patient (PtGA) and Provider (PrGA) Global Assessment of Disease Activity, Disease Activity Score (DAS) and Disease Activity Score with 28-Joint Counts (DAS28), Simplified Disease Activity Index (SDAI), Clinical Disease Activity Index (CDAI), Patient Activity Score (PAS) and Patient Activity Score-II (PASII), Routine Assessment of Patient Index Data (RAPID), Rheumatoid Arthritis Disease Activity Index (RADAI) and Rheumatoid Arthritis Disease Activity Index-5 (RADAI-5), Chronic Arthritis Systemic Index (CASI), Patient-Based Disease Activity Score With ESR (PDAS1) and Patient-Based Disease Activity Score without ESR (PDAS2), and Mean Overall Index for Rheumatoid Arthritis (MOI-RA). Arthritis Care Res (Hoboken) 2011 Nov;63 Suppl 11:S14-S36 [FREE Full text] [doi: 10.1002/acr.20621] [Medline: 22588741]

90. Israeli E, Ryan JD, Shafer L, Bernstein CN. Younger age at diagnosis is associated with panenteric, but not more aggressive, Crohn's disease. Clin Gastroenterol Hepatol 2014 Jan;12(1):72-79.e1. [doi: 10.1016/j.cgh.2013.06.027] [Medline: 23880115]

91. Kurtzke JF. Rating neurologic impairment in multiple sclerosis: an expanded disability status scale (EDSS). Neurology 1983 Nov;33(11):1444-1452. [Medline: 6685237]

92. Pincus T, Summey JA, Soraci Jr SA, Wallston KA, Hummon NP. Assessment of patient satisfaction in activities of daily living using a modified Stanford Health Assessment Questionnaire. Arthritis Rheum 1983 Nov;26(11):1346-1353. [Medline: 6639693]

93. Maska L, Anderson J, Michaud K. Measures of functional status and quality of life in rheumatoid arthritis: Health Assessment Questionnaire Disability Index (HAQ), Modified Health Assessment Questionnaire (MHAQ), Multidimensional Health Assessment Questionnaire (MDHAQ), Health Assessment Questionnaire II (HAQ-II), Improved Health Assessment Questionnaire (Improved HAQ), and Rheumatoid Arthritis Quality of Life (RAQoL). Arthritis Care Res (Hoboken) 2011 Nov;63 Suppl 11:S4-13 [FREE Full text] [doi: 10.1002/acr.20620] [Medline: 22588760]

94. Harris PA, Taylor R, Thielke R, Payne J, Gonzalez N, Conde JG. Research electronic data capture (REDCap)--a metadata-driven methodology and workflow process for providing translational research informatics support. J Biomed Inform 2009 Apr;42(2):377-381 [FREE Full text] [doi: 10.1016/j.jbi.2008.08.010] [Medline: 18929686]

95. Isik A, Koca SS, Ozturk A, Mermi O. Anxiety and depression in patients with rheumatoid arthritis. Clin Rheumatol 2007 Jun;26(6):872-878. [doi: 10.1007/s10067-006-0407-y] [Medline: 16941197]

96. Mikocka-Walus A, Knowles SR, Keefer L, Graff L. Controversies revisited: a systematic review of the comorbidity of depression and anxiety with inflammatory bowel diseases. Inflamm Bowel Dis 2016 Mar;22(3):752-762. [doi: 10.1097/MIB.0000000000000620] [Medline: 26841224]

97. Marrie RA, Reingold S, Cohen J, Stuve O, Trojano M, Sorensen P, et al. The incidence and prevalence of psychiatric disorders in multiple sclerosis: a systematic review. Mult Scler 2015 Mar;21(3):305-317 [FREE Full text] [doi: 10.1177/1352458514564487] [Medline: 25583845]

98. Walker JR, Ediger JP, Graff LA, Greenfeld JM, Clara I, Lix L, et al. The Manitoba IBD cohort study: a population-based study of the prevalence of lifetime and 12-month anxiety and mood disorders. Am J Gastroenterol 2008 Aug;103(8):1989-1997. [doi: 10.1111/j.1572-0241.2008.01980.x] [Medline: $\underline{18796096}$ ]

99. Stafford L, Berk M, Jackson HJ. Validity of the Hospital Anxiety and Depression Scale and Patient Health Questionnaire-9 to screen for depression in patients with coronary artery disease. Gen Hosp Psychiatry 2007;29(5):417-424. [doi: 10.1016/j.genhosppsych.2007.06.005] [Medline: 17888808] 
100. Bland JM, Altman DG. Cronbach's alpha. Br Med J 1997 Feb 22;314(7080):572 [FREE Full text] [Medline: 9055718$]$

101. Bhandari S, Larson ME, Kumar N, Stein D. Association of inflammatory bowel disease (IBD) with depressive symptoms in the United States population and independent predictors of depressive symptoms in an IBD population: a NHANES study. Gut Liver 2017 Jul 15;11(4):512-519 [FREE Full text] [doi: 10.5009/gnl16347] [Medline: 28395506]

102. Ediger JP, Walker JR, Graff L, Lix L, Clara I, Rawsthorne P, et al. Predictors of medication adherence in inflammatory bowel disease. Am J Gastroenterol 2007 Jul;102(7):1417-1426. [doi: 10.1111/j.1572-0241.2007.01212.x] [Medline: 17437505]

103. de Groof EJ, Rossen NG, van Rhijn BD, Karregat EP, Boonstra K, Hageman I, et al. Burden of disease and increasing prevalence of inflammatory bowel disease in a population-based cohort in the Netherlands. Eur J Gastroenterol Hepatol 2016 Sep;28(9):1065-1072. [doi: 10.1097/MEG.0000000000000660] [Medline: 27281507]

104. Fiest KM, Fisk JD, Patten SB, Tremlett H, Wolfson C, Warren S, CIHR Team in the Epidemiology and Impact of Comorbidity on Multiple Sclerosis (ECoMS). Comorbidity is associated with pain-related activity limitations in multiple sclerosis. Mult Scler Relat Disord 2015 Sep;4(5):470-476 [FREE Full text] [doi: 10.1016/j.msard.2015.07.014] [Medline: 26346797]

105. Metz LM, Greenfield J, Marrie RA, Jette N, Blevins G, Svenson LW, et al. Medical tourism for CCSVI procedures in people with multiple sclerosis: an observational study. Can J Neurol Sci 2016 May;43(3):360-367. [doi: 10.1017/cjn.2015.350] [Medline: 26891024]

106. Siebert S, Lyall DM, Mackay DF, Porter D, McInnes IB, Sattar N, et al. Characteristics of rheumatoid arthritis and its association with major comorbid conditions: cross-sectional study of 502649 UK Biobank participants. RMD Open 2016;2(1):e000267 [FREE Full text] [doi: 10.1136/rmdopen-2016-000267] [Medline: 27403335]

107. Dougados M, Soubrier M, Antunez A, Balint P, Balsa A, Buch MH, et al. Prevalence of comorbidities in rheumatoid arthritis and evaluation of their monitoring: results of an international, cross-sectional study (COMORA). Ann Rheum Dis 2014 Jan;73(1):62-68 [FREE Full text] [doi: 10.1136/annrheumdis-2013-204223] [Medline: 24095940]

108. Reed GW, Collier DH, Koenig AS, Saunders KC, Pappas DA, Litman HJ, et al. Clinical and demographic factors associated with change and maintenance of disease severity in a large registry of patients with rheumatoid arthritis. Arthritis Res Ther 2017 Apr 27;19(1):81 [FREE Full text] [doi: 10.1186/s13075-017-1289-x] [Medline: 28449692]

109. Galea S, Tracy M. Participation rates in epidemiologic studies. Ann Epidemiol 2007 Sep;17(9):643-653. [doi: 10.1016/j.annepidem.2007.03.013] [Medline: 17553702]

110. Hessol NA, Schneider M, Greenblatt RM, Bacon M, Barranday Y, Holman S, Women's Interagency Human Immunodeficiency Virus Collaborative Study Group. Retention of women enrolled in a prospective study of human immunodeficiency virus infection: impact of race, unstable housing, and use of human immunodeficiency virus therapy. Am J Epidemiol 2001 Sep 15;154(6):563-573. [Medline: 11549562]

111. Hanna KM, Scott LL, Schmidt KK. Retention strategies in longitudinal studies with emerging adults. Clin Nurse Spec 2014;28(1):41-45 [FREE Full text] [doi: 10.1097/NUR.0000000000000020] [Medline: 24309576]

112. Yu S, Alper HE, Nguyen A, Brackbill RM, Turner L, Walker DJ, et al. The effectiveness of a monetary incentive offer on survey response rates and response completeness in a longitudinal study. BMC Med Res Methodol 2017 Apr 26;17(1):77 [FREE Full text] [doi: 10.1186/s12874-017-0353-1] [Medline: 28446131]

113. Koch-Henriksen N, Sørensen PS. The changing demographic pattern of multiple sclerosis epidemiology. Lancet Neurol 2010 May;9(5):520-532. [doi: 10.1016/S1474-4422(10)70064-8] [Medline: 20398859]

114. Chernikova E. Statcan. Ottawa: Statistics Canada, Social and Aboriginal Statistics Division; 2016. Aboriginal Peoples: Fact Sheet for Manitoba URL: http://www.statcan.gc.ca/pub/89-656-x/89-656-x2016008-eng.htm [accessed 2018-01-01] [WebCite Cache ID 6w9KFXipv]

115. Bove R. Women's issues in multiple sclerosis. Semin Neurol 2016 Apr;36(2):154-162. [doi: 10.1055/s-0036-1579736] [Medline: 27116722]

116. Talsania M, Scofield RH. Menopause and rheumatic disease. Rheum Dis Clin North Am 2017 May;43(2):287-302. [doi: 10.1016/j.rdc.2016.12.011] [Medline: 28390570]

117. de Kruif M, Spijker AT, Molendijk ML. Depression during the perimenopause: a meta-analysis. J Affect Disord 2016 Dec;206:174-180. [doi: 10.1016/j.jad.2016.07.040] [Medline: 27475888]

\section{Abbreviations}

ACR/EULAR: American College of Rheumatology/European League Against Rheumatism

CCHS: Canadian Community Health Survey

CDAI: Clinical Disease Activity Index

D-FIS: Fatigue Impact Scale for Daily Use

DNA: deoxyribonucleic acid

EDSS: Expanded Disability Status Scale

GED: General Education Diploma

HBDAI: Harvey Bradshaw Disease Activity Index

HRQOL: health-related quality of life 
IBD: inflammatory bowel disease

IMID: immune-mediated inflammatory diseases

MCS: mental component score

mHAQ: Modified Health Assessment Questionnaire

MS: multiple sclerosis

PCS: physical component score

PSS: Perceived Stress Scale

PTI: Powell Tuck Index

RA: rheumatoid arthritis

SCID: structured clinical interview for DSM-IV-TR Axis I Disorders-Research version

SD: standard deviation

WPAI: Work Productivity and Activity Impairment Questionnaire

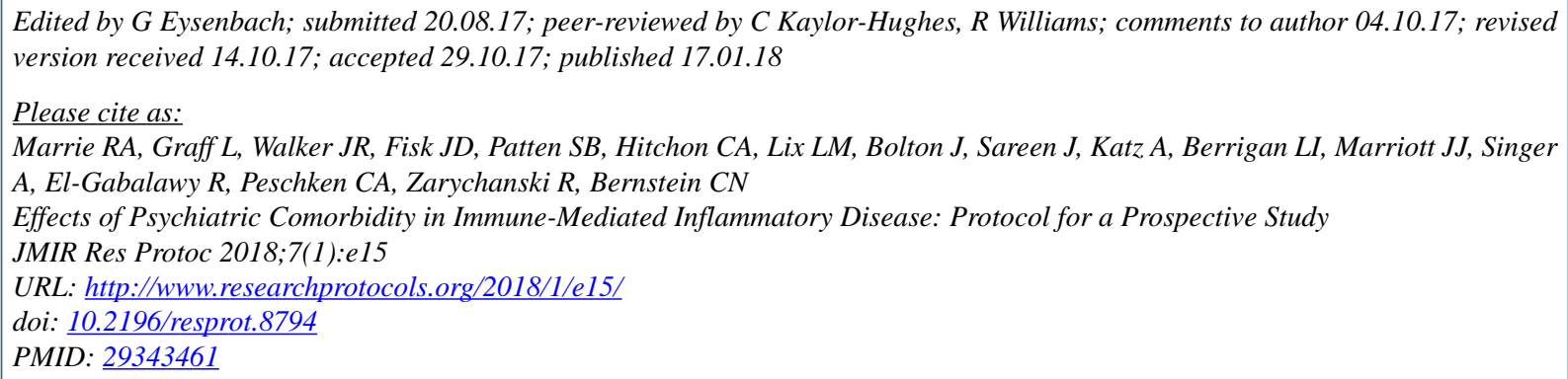

CRuth Ann Marrie, Lesley Graff, John R Walker, John D Fisk, Scott B Patten, Carol A Hitchon, Lisa M Lix, James Bolton, Jitender Sareen, Alan Katz, Lindsay I Berrigan, James J Marriott, Alexander Singer, Renée El-Gabalawy, Christine A Peschken, Ryan Zarychanski, Charles N Bernstein. Originally published in JMIR Research Protocols (http://www.researchprotocols.org), 17.01.2018. This is an open-access article distributed under the terms of the Creative Commons Attribution License (https://creativecommons.org/licenses/by/4.0/), which permits unrestricted use, distribution, and reproduction in any medium, provided the original work, first published in JMIR Research Protocols, is properly cited. The complete bibliographic information, a link to the original publication on http://www.researchprotocols.org, as well as this copyright and license information must be included. 